\title{
PENGARUH WAKTU DAN SUHU PEMBAKARAN DALAM PEMBUATAN ABU DARI KULIT BUAH MARKISA SEBAGAI SUMBER ALKALI
}

\author{
Hari Surya Purnama, Herbert, Rondang Tambun \\ Departemen Teknik Kimia, Fakultas Teknik, Universitas Sumatera Utara, \\ Jl. Almamater Kampus USU Medan 20155, Indonesia \\ Email : harisuryapurnama@yahoo.co.id
}

\begin{abstract}
Abstrak
Penelitian ini bertujuan untuk menentukan waktu dan suhu optimum pembakaran pada pembuatan abu dari kulit buah markisa ungu (Parcilora idollis Sims $f$ edulis Deg.). Penelitian ini diawali dengan mengeringkan kulit buah markisa dan dilakukan pembakaran untuk memperoleh abu dari kulit buah markisa. Pembakaran dilakukan dengan menggunakan muffle furnace dengan variasi waktu yaitu 1, 2, $3,4,5$ jam dan variasi suhu pembakaran $400{ }^{\circ} \mathrm{C}, 500{ }^{\circ} \mathrm{C}, 600{ }^{\circ} \mathrm{C}, 700{ }^{\circ} \mathrm{C}$. Kandungan kalium pada abu akan diekstraksi dengan aquadest dengan perbandingan volume 1 : 10 selama 24 jam. Respon yang diamati adalah rendemen abu, normalitas, $\mathrm{pH}$, daya hantar listrik dan kandungan kalium oksida (\% $\mathrm{K}_{2} \mathrm{O}$ ). Hasil abu terbaik yang diperoleh adalah pada waktu 5 jam dan suhu $500{ }^{\circ} \mathrm{C}$. Abu tersebut dianalisa dengan Atomic Absorption Spectroscopy dimana hasil maksimum yang diperoleh kandungan $\mathrm{K}_{2} \mathrm{O}$ nya sebesar $39,95 \%$.
\end{abstract}

Kata kunci : abu, kulit buah markisa, kalium, pembakaran

\begin{abstract}
The purpose of this study was to determine the optimum of combustion time and temperature of ash production from purple passion fruit peel (Parcilora idollis Sims $f$ edulis Deg.). The experiment was begun to dry passion fruit peel, then combustion to obtaine the ash from passion fruit peel. The combustion was done by muffle furnace which time variables were from 1, 2, 3, 4, 5 hours and burning temperature variables were from $400{ }^{\circ} \mathrm{C}, 500{ }^{\circ} \mathrm{C}, 600{ }^{\circ} \mathrm{C}, 700{ }^{\circ} \mathrm{C}$. The potassium that contained in ash have been extracted by distilled water with volume comparison was $1: 10$ for 24 hours. Observed responses were ash content, normality, $\mathrm{pH}$, conductivity and potassium oxide content $\left(\% \mathrm{~K}_{2} \mathrm{O}\right)$. The best result of ash was in 5 hours with temperature $500{ }^{\circ} \mathrm{C}$. The ash was analyzed by using AAS Atomic Absorption Spectroscopy, and 39,95 \% of potassium oxide $\left(\mathrm{K}_{2} \mathrm{O}\right)$ content was obtained as maximum result.
\end{abstract}

Keywords : ash, passion fruit peel, potassium, combustion

\section{Pendahuluan}

Tanaman markisa (passiflora edulis) sudah dibudidayakan sejak lama dan sudah populer baik di dalam maupun di luar negeri. Buahnya mengandung berbagai zat yang berguna, seperti karbohidrat, protein, lemak dan berbagai vitamin serta mineral. Markisa asam (passiflora edulis) sudah disebarkan secara merata di Indonesia, khususnya di Berastagi, Sumatera Utara, yang merupakan salah satu daerah penghasil markisa. Agribisnis komoditi ini sudah lama ditunjang oleh industri sari buah dan jus markisa yang pengolahannya menghasilkan limbah, yaitu berupa kulit buah markisa yang jumlahnya mencapai $50,38 \%$ dari total buah segar markisa [10]. Secara nasional, sentra produksi markisa terletak di Sumatera Utara dan Sulawesi Selatan. Di Sumatera Utara sendiri, industri pengolahan hortikultura menjadi pangan cukup berkembang. PT Gunung Sibayak Intisari mampu berproduksi $10-15$ ton per hari dengan limbah berupa biji dan kulit buah sebanyak 2-3 ton per hari. Dilihat dari produksi maupun kandungan zat-zat makanan yang terdapat didalamnya, tentunya limbah ini mempunyai potensi yang cukup besar untuk diolah. Dari aspek nutrisi, kulit buah markisa mengandung bahan organik $76 \%$, energi tercerna $2809 \mathrm{kkal} / \mathrm{kg}$, protein kasar 18,1\% [24], dan kandungan mineral terbanyaknya adalah kalium 33,66 $\mathrm{g} / \mathrm{kg}$ [14]. Sehingga dapat dikatakan bahwa kandungan alkali pada kulit buah markisa cukup besar.

Limbah kulit buah markisa dan biji buah markisa (BBM) terbuang dalam penyaringan sari buah markisa. Setiap per kilogram bahan baku buah markisa dihasilkan limbah sebanyak 66-75\% KBM dan BBM tergantung dari varietas buah. Buah markisa berwarna hijau limbahnya sebesar $75 \%$ dan varietas warna hitam limbahnya sebanyak $66 \%$ [15]. Adanya bahan-bahan buangan yang berupa limbah industri tersebut, tentunya menuntut suatu teknologi yang bisa mengolah dan meningkatkan kualitas atau mutu bahan limbah tersebut supaya dapat dimanfaatkan sebagai sumber alkali untuk pembuatan sabun. 


\section{Teori}

Pirolisis merupakan salah satu metode CVD (Chemical Vapor Deposition) dimana bahan-bahan organik akan terurai pada temperatur tinggi dibawah kondisi non-oksidatif (tidak ada oksigen yang masuk) [19]. Pada proses pirolisis unsurunsur bukan karbon seperti hidrogen $(\mathrm{H})$ dan oksigen (O) akan hilang hingga menyisakan sebanyak mungkin karbon (C) dalam bahan. Proses inilah yang disebut karbonisasi [8]. Pada proses dehidrasi bahan baku dipanaskan sampai $170{ }^{\circ} \mathrm{C}$. Selanjutnya temperatur diatas $170{ }^{\circ} \mathrm{C}$ akan menghasilkan $\mathrm{CO}, \mathrm{CO}_{2}$ dan asam asetat. Pada temperatur $275{ }^{\circ} \mathrm{C}$ terjadi dekomposisi yang menghasilkan tar, metanol dan hasil sampingan lainnya. Pembentukan karbon terjadi pada temperatur $400-600{ }^{\circ} \mathrm{C}$ [21].

Faktor-faktor yang mempengaruhi proses pirolisis adalah sebagai berikut :

a. Waktu

Semakin lama waktu proses pirolisis berlangsung, produk yang dihasilkannya (residu padat, tar, dan gas) makin naik. Kenaikan itu sebatas sampai dengan waktu tak hingga $(\tau)$ yaitu waktu yang diperlukan sampai dengan hasil padatan residu, tar, dan gas mencapai konstan. Tetapi jika melebihi waktu optimal maka karbon akan teroksidasi oleh oksigen (terbakar), menjadi karbondioksida dan abu.

b. Suhu

Sesuai dengan persamaan Arhenius, semakin tinggi suhu maka nilai konstanta dekomposisi termal makin besar akibatnya laju pirolisis bertambah dan konversi naik. [7]

c. Kadar Air

Kadar air umpan besar sekali pengaruhnya. Hal ini disebabkan karena uap air yang diusir makin banyak. Kadar air untuk bermacam-macam zat tidak sama.

d. Ukuran Bahan

Ukuran bahan berpengaruh sekali pada perataan panas. Makin kecil ukuran bahan makin cepat perataan keseluruhan umpan sehinggal pirolisis berjalan lebih sempurna [25].

Abu merupakan bahan anorganik yang tidak dapat dibakar dari sumber bahan bakar yang tersisa setelah melalui pembakaran sempurna dan mengandung fraksi mineral dari biomassa tersebut Potensial pemanfaatan abu dipengaruhi oleh adanya kehadiran logam-logam berat yang tergantung dari sumber biomassa [17]. Dalam kayu, abu terkandung kurang dari 2 persen, sedangkan bahan-bahan tanaman perkebunan dapat mencapai antara 5-10\% dan mencapai 30-40\% dalam sekam padi [20]. Produk dasar biomassa menghasilkan residu abu, yang melibatkan proses termokimia yang meliputi pembakaran, pirolisis dan insinerasi dari biomassa tersebut [1]. Komposisi dari abu juga tergantung pada jenis tumbuhan, kondisi pertumbuhan dan fraksi abu [6].

Karbonat terbentuk pada temperatur yang rendah sedangkan abu terbentuk pada temperatur yang tinggi didalam keadaan atmosfir oksigen yang secara utama membentuk logam oksida. Pada temperatur yang tinggi, kalium oksida yang terbentuk akan bereaksi dengan unsur-unsur lain dan membentuk ikatan kimia, pada keadaan yang sama terjadi disosiasi dari kalium karbonat dan senyawa kalium oksida akan mengalami penguapan dengan cepat sedangkan temperatur yang rendah, panas akan berpindah ke permukaan $\mathrm{KOH}$ sehingga $\mathrm{K}_{2} \mathrm{CO}_{3}$ akan terbentuk [18].

Kombinasi kandungan oksigen tinggi dengan bahan organik volatil yang terkandungan didalam biomassa menunjukkan potensi terjadinya penguapan pada sejumlah bahan anorganik selama pembakaran. Unsur alkali juga secara langsung menguap pada suhu operasi normal furnace [2]. K, $\mathrm{Na}, \mathrm{S}$ dan $\mathrm{Cl}$ merupakan senyawa-senyawa volatil yang terbentuk dari abu berdasarkan cara pembakaran biomassa, begitu pula hanya dengan logam berat volatil ( $\mathrm{Zn}$ dan $\mathrm{Cd}$ ) akan terlepas dari bahan yang dibakar menjadi fasa gas dan kemudian bereaksi dalam kondisi fasa gas [4]

Banyak penelitian terdahulu dilakukan untuk memanfaatkan abu dari kulit buah sebagai sumber alkali. Olabanji dkk (2012) melakukan penelitian mengenai analisa logam dari abu kulit pisang raja dan kulit pisang sebagai turunan alkali dalam pembuatan sabun [9]. Dan juga penelitian Babayemi dkk (2010) mengenai evaluasi komposisi dan sifat kimia dari abu dari bermacam material tumbuhan. Jenis tumbuhan, tanah tempat tumbuhan itu tumbuh, pemakaian bahan kimia yang sesuai dan teknologi adalah beberapa faktor yang mempengaruhi antara sifat dan jumlah turunan komponen dari abu [11].

\section{Metodologi Penelitian \\ Bahan dan Alat}

Bahan yang digunakan dalam penelitian ini adalah kulit buah markisa ungu segar (Parcilora idollis Sims $f$ edulis Deg.) sebagai bahan baku, deionized water, aquadest, larutan $\mathrm{CH}_{3} \mathrm{COOH}$, indikator phenolphthalein. Alat yang digunakan meliputi Muffle furnace sebagai tempat pembakaran sampel, oven sebagai tempat pengeringan untuk menghitung kadar air, cawan porselin sebagai wadah sampel saat pembakaran, neraca analitik untuk mengukur massa bahan, Beaker glass sebagai wadah untuk mengekstrak abu, gelas ukur untuk mengukur volume larutan, Corong untuk membantu menuang larutan, statif dan klem, buret sebagai alat titrasi, pipet tetes untuk mengambil larutan dalam jumlah kecil, Erlenmeyer sebagai wadah titrasi, stopwatch untuk 
mengukur waktu ekstraksi, kertas saring sebagai alat pemisah filtrat dan residu.

\section{Persiapan Pembuatan Abu}

Pada proses pembuatan abu sebelumnya kulit buah markisa segar dimasukkan ke dalam oven pada suhu $105{ }^{\circ} \mathrm{C}$ selama 5 jam hingga berat konstan untuk memperoleh kadar air kulit buah markisa. Selanjutnya kulit buah markisa segar dikeringkan dibawah sinar matahari selama 1x24 jam, kemudian ditimbang kulit buah markisa sebanyak 15 gr dimasukkan kedalam muffle furnace dengan waktu dan suhu pembakaran yang ditentukan. Abu hasil pembakaran tersebut ditimbang. Rendemen abu dapat dihitung dengan persamaan 1 [12] :

Rendemen $\mathrm{Abu}=\left(\mathrm{M}_{2} / \mathrm{M}_{1}\right) \times 100 \%$

Dimana $\mathbf{M}_{1}$ adalah berat sampel awal (gr) dan $\mathbf{M}_{2}$ adalah berat akhir/abu (gr).

Kemudian sampling abu sebanyak 0,5 gr di analisa kadar $\mathrm{K}_{2} \mathrm{O}$ nya menggunakan Atomic Absorption Spectrophotometer $(A A S)$.

\section{Penentuan Normalitas}

Untuk menentukan normalitas larutan ekstrak alkali, dilakukan dengan metode titrasi asam basa. 0,5 gr abu dilarutkan dalam $5 \mathrm{ml}$ aquadest dan direndam selama 24 jam, kemudian larutan tersebut disaring dengan menggunakan kertas saring dan filtratnya ditampung pada erlenmeyer. Lalu dilakukan titrasi menggunakan asam asetat $\left(\mathrm{CH}_{3} \mathrm{COOH}\right) \quad 0,1 \quad \mathrm{~N}$ dengan menambahkan indikator phenolphthalein. Normalitas tiap ekstrak dapat dihitung dari jumlah volume titrasi.

\section{Penentuan pH dan Daya Hantar Listrik}

Dilarutkan 0,5 gr abu dalam $5 \mathrm{ml}$ aquadest dan direndam selama 15 menit, kemudian larutan tersebut disaring dengan menggunakan kertas saring dan filtratnya ditampung pada beaker glass. Lalu diukur $\mathrm{pH}$ setiap ekstrak menggunakan $\mathrm{pH}$ meter dan daya hantar listriknya diukur menggunakan alat Hanna conductivity meter.

\section{Hasil dan Pembahasan \\ Pembuatan Abu Kulit Buah Markisa}

Pemanfaatan kulit buah markisa sebagai sumber alkali dapat dilakukan dengan 2 tahap yaitu pengurangan kadar air kulit markisa dan pembakaran kulit markisa kering dengan menggunakan furnace. Kulit markisa dikeringkan di bawah sinar matahari hingga kulit markisa menjadi kering.

Hasil pengeringan kulit markisa yang dilakukan ini mengurangi kadar air yang terdapat pada kulit hingga 66,6 \% dari berat awal. Kulit markisa kering hasil pengeringan dapat dilihat pada gambar 1 .

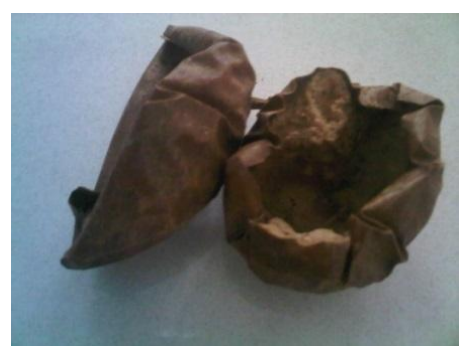

\section{Gambar 1. Kulit Buah Markisa Kering}

Kulit markisa yang telah kering dipotong kecil dan sebanyak 15 gr kulit kering dibakar dengan menggunakan muffle furnace untuk pengaruh waktu dengan suhu pembakaran $600{ }^{\circ} \mathrm{C}$ dan variasi waktu 1, 2, 3, 4 dan 5 jam sedangkan untuk pengaruh suhu dengan waktu 1 dan 5 jam dan variasi suhu pembakaran 400, 500, 600 dan $700{ }^{\circ} \mathrm{C}$. Abu hasil pembakaran yang diperoleh dilakukan beberapa analisa yaitu rendemen abu, normalitas kandungan basa, $\mathrm{pH}$, konduktivitas dan kadar $\mathrm{K}_{2} \mathrm{O}$.

Pengaruh Waktu dan Suhu Pembakaran $\left({ }^{\circ} \mathrm{C}\right)$ terhadap Rendemen Abu (\%) pada 15 Gr Sampel Kulit Kering

Pembakaran kulit buah markisa kering terhadap rendemen abu yang dihasilkan dapat dilihat pada gambar 2 .

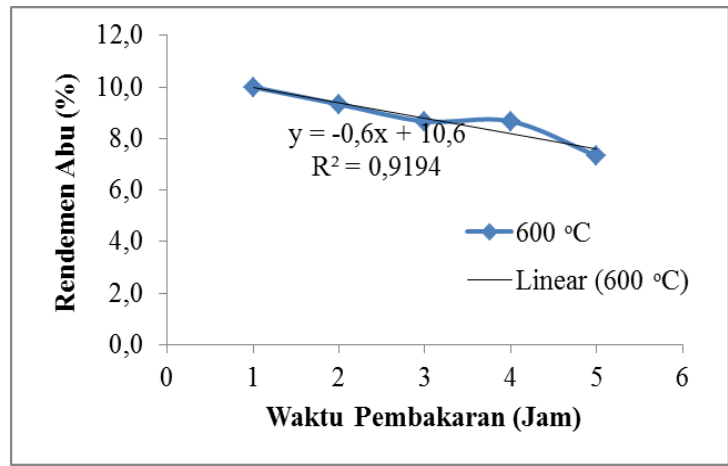

Gambar 2 (a)

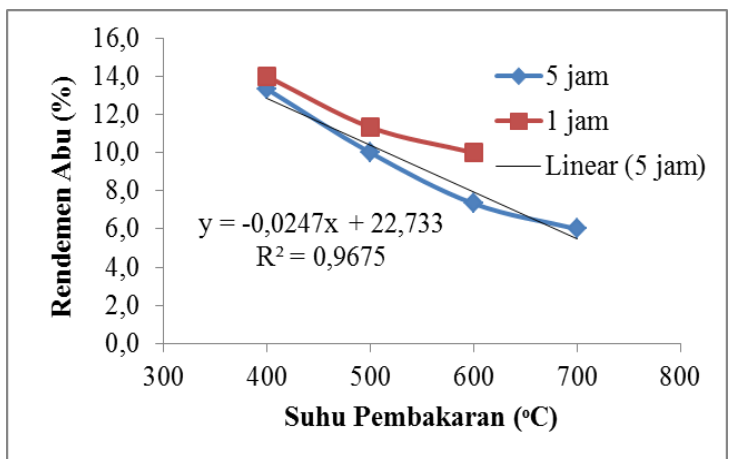

Gambar 2 (b)

Gambar 2. Pengaruh Waktu dan Suhu Pembakaran $\left({ }^{\circ} \mathrm{C}\right)$ terhadap Rendemen Abu (\%) pada 15 gr Sampel Kulit Kering 
Dari gambar 2 dapat dilihat bahwa penambahan waktu pembakaran menghasilkan rendemen abu yang semakin menurun, begitu juga terhadap penambahan suhu pembakaran menghasilkan rendeman abu semakin menurun. Dimana dapat dilihat pada suhu $400{ }^{\circ} \mathrm{C}$ dengan waktu pembakaran 1 dan 5 jam menghasilkan rendemen yang semakin menurun dari $14 \%$ menjadi $13,33 \%$. Suhu pembakaran merupakan faktor penting yang menentukan abu yang dihasilkan dari suatu tumbuhan [18]. Karakter dari lapisan abu tergantung pada suhu, kecepatan aliran dan konsentrasi oksigen [16]. Pembakaran material tumbuhan pada suhu yang tinggi menghasilkan dekomposisi beberapa komponen anorganik dan juga pengurangan berat [11].

Rendahnya rendemen abu ini dikarenakan reaksi antara karbon dengan uap air semakin meningkat dengan bertambahnya suhu dan lamanya waktu pembakaran, sehingga karbon yang bereaksi menjadi $\mathrm{CO}_{2}$ dan $\mathrm{H}_{2}$ menjadi banyak, sebaliknya jumlah abu yang dihasilkan semakin sedikit [23].

Pengaruh Waktu dan Suhu Pembakaran $\left({ }^{\circ} \mathrm{C}\right)$ terhadap Normalitas (N) pada 0,5 Gr Sampel Abu

Hasil pembakaran yang diperoleh dari percobaan diekstraksi menggunakan aquadest, lalu disaring dan filtratnya dianalisa dengan metode titrasi menggunakan asam untuk mengetahui konsentrasi basa yang dikandung dari hasil pembakaran. Pengaruh suhu pembakaran terhadap normalitas ekstrak dari abu dapat dilihat pada gambar 3 .

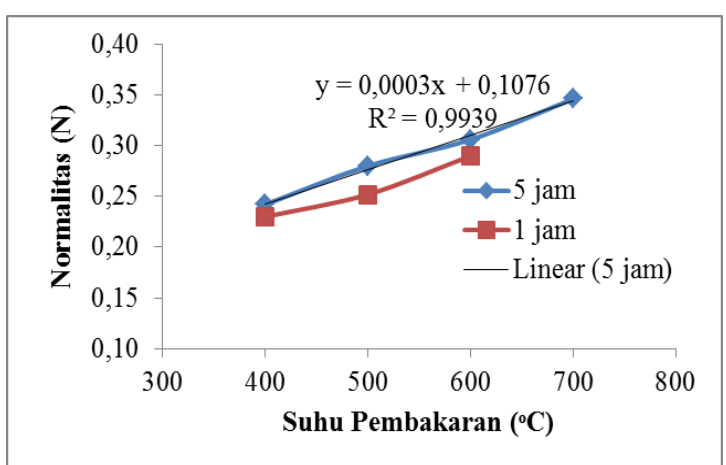

Gambar 3. Pengaruh Waktu dan Suhu Pembakaran $\left({ }^{\circ} \mathrm{C}\right)$ terhadap Normalitas (N) pada 0,5 gr Sampel Abu

Dari gambar 3 diperoleh pada waktu yang sama dengan bertambahnya suhu pembakaran maka normalitas dari ekstrak abu juga semakin bertambah. Begitu pula dengan bertambahnya waktu, normalitas juga semakin meningkat. Ekstrak alkali dari abu adalah alkali hidroksida yang dapat dijelaskan bahwa $\mathrm{K}_{2} \mathrm{O}$ dan atau $\mathrm{Na}_{2} \mathrm{O}$ terbentuk selama pembakaran material suatu tumbuhan dan larut di dalam air selama ekstraksi menjadi hidroksida. Tetapi hal itu dikatakan susunan $\mathrm{K}_{2} \mathrm{O}$ atau $\mathrm{Na}_{2} \mathrm{O}$ terbentuk dari akibat pembakaran logam murni ( $\mathrm{K}$ atau $\mathrm{Na}$ ) di udara, dimana $\mathrm{K}$ atau $\mathrm{Na}$ didalam material tumbuhan terikat dalam matrik organiknya [11].

Selain itu, kemampuan abu untuk melarut menjadi suatu fungsi dari jumlah komponenkomponen logam alkali dan garam-garam yang dapat larut lainnya (seperti klorida dan sulfat dari $\mathrm{K}$ dan $\mathrm{Na}$ ) yang terkandung didalam abu tergantung jenis tumbuhan yang dibakar. Komponen- komponen yang tidak larut pada abu mengandung silikat dan logam lain yang sukar larut didalam air. Ketika abu dilarutkan dengan air, hanya karbonat dan mungkin klorida serta sulfat dari logam alkali yang terdapat pada larutan, termasuk sebagian kecil logam lain yang tidak larut atau sukar larut [11].

\section{Pengaruh Waktu dan Suhu Pembakaran $\left({ }^{\circ} \mathrm{C}\right)$ terhadap PH pada 0,5 Gr Sampel Abu \\ Hasil pembakaran yang diperoleh dari} percobaan diekstraksi menggunakan aquadest, lalu disaring dan filtratnya dianalisa untuk mengetahui $\mathrm{pH}$ dari abu hasil pembakaran. Pengaruh waktu dan suhu pembakaran terhadap $\mathrm{pH}$ dari abu dapat dilihat pada gambar 4 .

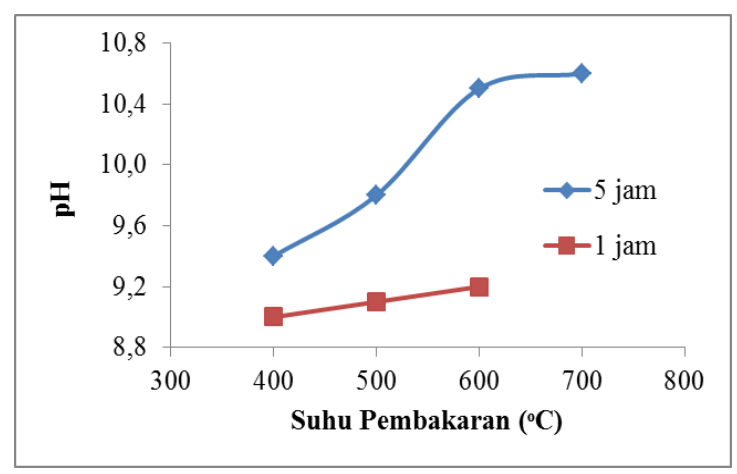

Gambar 4. Pengaruh Waktu dan Suhu Pembakaran $\left({ }^{\circ} \mathrm{C}\right)$ terhadap $\mathrm{pH}$ pada $0,5 \mathrm{gr}$ Sampel Abu

Dari gambar 4 dapat dilihat bahwa penambahan suhu pembakaran menghasilkan $\mathrm{pH}$ yang semakin meningkat, begitu juga terhadap penambahan waktu pembakaran menghasilkan $\mathrm{pH}$ semakin meningkat dimana dapat dilihat pada suhu $400{ }^{\circ} \mathrm{C}$ dengan waktu pembakaran 1 dan 5 jam menghasilkan $\mathrm{pH}$ yang meningkat dari 9 menjadi 9,4 .

Karbonat terbentuk pada temperatur yang rendah sedangkan abu terbentuk pada temperatur yang tinggi didalam keadaan atmosfir oksigen yang secara utama membentuk logam oksida [18]. 
Dengan terbentuknya senyawa alkali karbonat maupun alkali oksida pada abu yang ditambahkan air. Campuran tersebut akan menjadi larutan yang bersifat basa.

Pengaruh Waktu dan Suhu Pembakaran $\left({ }^{\circ} \mathrm{C}\right)$ terhadap Daya Hantar Listrik $(\mu \mathrm{S} / \mathrm{cm})$ pada 0,5 Gr Sampel Abu

Hasil pembakaran yang diperoleh dari percobaan diekstraksi menggunakan deionized water, lalu disaring dan filtratnya dianalisa untuk mengetahui daya hantar listrik dari abu hasil pembakaran. Pengaruh waktu dan suhu pembakaran terhadap daya hantar listrik dari abu dapat dilihat pada gambar 5 .

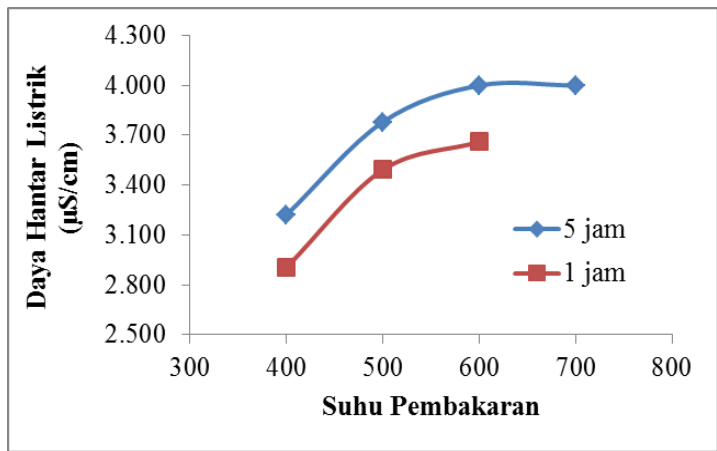

Gambar 5. Pengaruh Waktu dan Suhu Pembakaran terhadap Daya Hantar Listrik $(\mu \mathrm{S} / \mathrm{cm})$ pada 0,5 gr Sampel Abu

Dari gambar 5 dapat dilihat bahwa penambahan suhu pembakaran menghasilkan daya hantar listrik yang semakin meningkat, begitu juga terhadap penambahan waktu pembakaran menghasilkan daya hantar listrik semakin meningkat. Dimana dapat dilihat pada suhu $400{ }^{\circ} \mathrm{C}$ dengan waktu pembakaran 1 dan 5 jam menghasilkan daya hantar listrik yang meningkat dari 2904 menjadi $3220 \mu \mathrm{S} / \mathrm{cm}$.

Konduktivitas listrik berhubungan dengan kemampuan suatu bahan untuk mengalirkan arus listrik. Sifat konduktivitas pada berbagai bahan berbeda-beda, tergantung pada kandungan bahan penghantamya. konduktivitas listrik larutan dipengaruhi oleh jumlah ion, mobilitas ion, tingkat oksidasi serta suhu. Semakin besar nilai daya hantar listrik berarti kemampuan dalam menghantarkan listrik semakin kuat [26].

Pada konduktor elektrolit elektron mengalir dibawa oleh ion-ion, sedangkan yang dapat menghasilkan ion antara lain asam, basa dan garam. Daya hantar listrik berhubungan dengan $\mathrm{pH}$ suatu bahan. Pada kondisi asam, $\mathrm{pH}$ yang memiliki tingkat keasaman yang kuat akan menghasilkan daya hantar listrik yang besar, dan pada keadaan basa, $\mathrm{pH}$ yang memiliki tingkat kebasaan yang besar akan menghasilkan daya hantar listrik yang besar [26].

Pengaruh Waktu dan Suhu Pembakaran $\left({ }^{\circ} \mathrm{C}\right)$ terhadap Kadar $\mathrm{K}_{2} \mathrm{O}(\%)$ pada $0,5 \mathrm{Gr}$ Sampel Abu

Pengaruh waktu dan suhu pembakaran kulit buah markisa kering terhadap kadar $\mathrm{K}_{2} \mathrm{O}$ pada abu hasil pembakaran dapat dilihat pada gambar 6 .

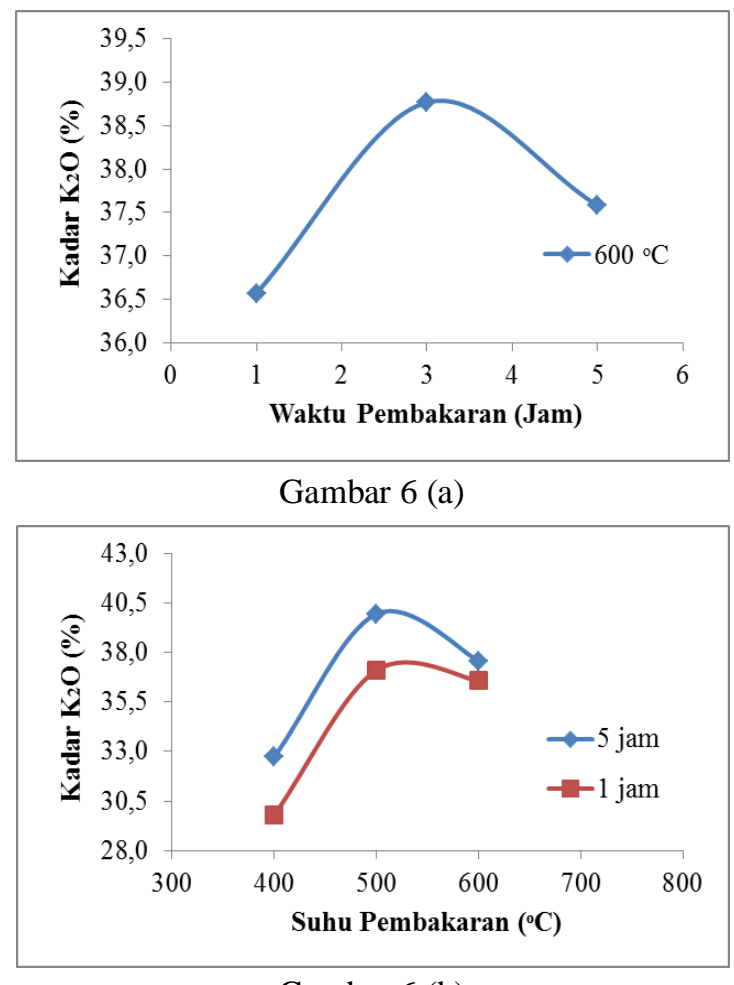

Gambar 6 (b)

Gambar 6. Pengaruh Waktu dan Suhu Pembakaran $\left({ }^{\circ} \mathrm{C}\right)$ terhadap Kadar $\mathrm{K}_{2} \mathrm{O}(\%)$ pada 0,5 gr Sampel Abu

Dari gambar 6 (a) dapat dilihat bahwa penambahan waktu pembakaran 1-3 jam menghasilkan kadar $\mathrm{K}_{2} \mathrm{O}$ yang semakin meningkat akan tetapi pada waktu 5 jam kadar $\mathrm{K}_{2} \mathrm{O}$ yang dihasilkan menurun. Dari gambar 6 (b) dapat dilihat bahwa penambahan suhu pembakaran 400$500{ }^{\circ} \mathrm{C}$ menghasilkan kadar $\mathrm{K}_{2} \mathrm{O}$ yang semakin meningkat akan tetapi penambahan suhu $600{ }^{\circ} \mathrm{C}$ kadar $\mathrm{K}_{2} \mathrm{O}$ yang dihasilkan menurun. Sedangkan pada penambahan waktu pembakaran menghasilkan kadar $\mathrm{K}_{2} \mathrm{O}$ semakin meningkat dimana dapat dilihat pada suhu $400{ }^{\circ} \mathrm{C}$ dengan waktu pembakaran 1 dan 5 jam menghasilkan kadar $\mathrm{K}_{2} \mathrm{O}$ yang meningkat dari 29,79 menjadi $32,72 \%$.

Semakin tinggi suhu pada proses pengarangan sekam mengalami penurunan kadar $\mathrm{K}_{2} \mathrm{O}$ yang terlihat pada suhu mulai $600{ }^{\circ} \mathrm{C}$ [5]. Penurunan kadar $\mathrm{K}_{2} \mathrm{O}$ dapat terjadi karena logam 
$\mathrm{K}$ yang terkandung pada abu telah mengalami penguapan dapat dilihat dari titik didih logam $\mathrm{K}$ yaitu $760{ }^{\circ} \mathrm{C}[22]$.

Perlakuan dengan bertambahnya temperatur pada pembakaran, logam alkali, $\mathrm{K}$ dan $\mathrm{Na}$, membentuk logam oksida yang kurang stabil dibandingkan dengan unsur lainnya yang terkandung dalam abu. Secara teori, pada temperatur yang tinggi kandungannya dapat berkurang oleh adanya senyawa karbon. Oleh karena itu, senyawa oksida tersebut bereaksi dengan uap air untuk mencapai keadaan stabil dan menjadi senyawa volatil hidroksida, $\mathrm{KOH}_{(\mathrm{g})}$ dan $\mathrm{NaOH}_{(\mathrm{g})}$ [3].

Hasil ini juga sesuai dengan penelitian Dodson, (2011), pada pembakaran jerami gandum dengan semakin meningkatnya suhu pada 400-500 ${ }^{\circ} \mathrm{C}$ diperoleh ekstraksi kandungan kalium yang meningkat. Akan tetapi pada suhu $600-800{ }^{\circ} \mathrm{C}$ terjadi penurunan kandungan kalium seiring bertambahnya waktu dan suhu pembakaran. Penurunan yang terjadi setelah 10 menit pembakaran tidak terlalu signifikan dibandingkan selama 2 jam. Konsentrasi kalium dan klorida berkurang pada suhu yang lebih tinggi karena penguapan $\mathrm{KCl}$ dari abu. Analisis ini didasarkan pada asumsi tidak ada silika yang menguap selama pembakaran. Bagaimanapun, kandungan kalium selama ekstraksi tidak hanya dipengaruhi oleh penguapan kalium selama pembakaran tetapi juga karena susunan dari sedikit jenis kalium yang mudah larut [13].

\section{Kesimpulan}

Kondisi optimum yang diperlukan pada pembakaran kulit buah markisa dengan furnace pada waktu 5 jam dan suhu $500{ }^{\circ} \mathrm{C}$ dengan kadar $\mathrm{K}_{2} \mathrm{O}$ sebesar $39,95 \%$. Pembakaran dengan waktu 5 jam lebih baik dimana abu yang dihasilkan telah membentuk oksida sedangkan waktu 1 jam didapat masih banyaknya senyawa garam pada abu dengan ditandai perolehan nilai $\mathrm{pH}$ dan daya hantar listrik yang jauh lebih besar pada waktu 5 jam seiring bertambahnya suhu. Perlakuan suhu pembakaran yang semakin lama mengakibatkan normalitas, $\mathrm{pH}$ dan daya hantar listrik semakin bertambah. Logam alkali dapat mengalami penguapan selama proses pembakaran seperti pada suhu $600{ }^{\circ} \mathrm{C}$. Kandungan kalium pada abu kulit markisa dapat digunakan sumber larutan alkali.

\section{DAFTAR PUSTAKA}

[1] A.K. James, R. W. Thring, S. Helle dan H.S. Ghuman., Ash Management ReviewApplications of Biomass Bottom Ash, Energies, ISSN 1996-1073, hal. 3, 2012.
[2] B.M. Jenkins; R.R. Bakker; J.B. Wei, On the Properties of Washed Straw, Biomass and Bioenergy, 10(4), hal 177-200, 1996.

[3] Bale. C, Chartrand. P, Degterov. S. A, Eriksson, G, Hack, K., Ben Mahfoud. R, Melancon. J, Pelton, A. D, Petersen, S. FactSage thermochemical software and databases, Calphad, 26 (2), hal 189-228, 2002.

[4] B. Thomas, J. Markus dan Obernberger Ingwald., Aerosol Formation in Fixed-bed Biomass Furnaces-Results from Measurements and Modelling. Proc. of the internet. Conf. Science in Thermal and Chemical Biomass Conversion, 2004.

[5] C.L. Hwang, dan D.S.Wu, Properties of Cement Paste Containing Rice Husk Ash, ACI Third International Conference Proceedings, hal. 738, 1989.

[6] D. Ayhan, Potential Applications of Renewable Energy Sources, Biomass Combustion Problems in Boiler Power Systems and Combustion Related Environmental Issues, Prog. Energy Combust.Sci, hal. 31, 2005.

[7] E. Mulyadi, Degradasi Sampah Kota (Rubbish) dengan Proses Pirolisis, Jurnal Ilmiah Teknik Lingkungan, Vol 1, No. 1, 23, 2013.

[8] E. Budi, Tinjauan Proses Pembentukan dan Penggunaan Arang Tempururng Kelapa Sebagai Bahan Bakar, Jurnal Penelitian Sains, Vol 14, No.4(B),14406-25-14406-26, 2011.

[9] I. Oluremi Olabanji, E. Ayodele Oluyemi, and O. Solomon Ajayi, Metal Analyses of Ash derived alkalis from banana and plaintain peels (Musa spp). In Soap Making, African Journal of Biotechnology, Vol. 11 (99), 16512-16518, ISSN 1684-5315, 2012.

[10] I. Sembiring dan Tri Hesti Wahyuni, Pemanfaatan Kulit Buah Markisa (Passiflora Edulis) Fermentasi dengan Aspergillus Niger terhadap Karkas Ayam Boiler Umur 8 minggu, Jurnal Agribisnis peternakan, Vol 1, No. 3, 94, 2005.

[11] J.O. Babayemi., K.T. Dauda., D.O. Nwude and A.A.A. Kayode., Evaluation of the Composition and Chemistry of Ash and Potash from Various Plant Materials, Journal of Applied Sciences, 1-4, ISSN 1812-5654, 2010.

[12] J.O. Babayemi., K.T. Dauda., D.O. Nwude., A.A.A. Kayode., J.A. Ajiboye., E.R. Essien dan O.O. Abiona., Determination of Potash Alkali and Metal Contents of Ashes Obtained from Peels of some Varieties of Nigeria Grown Musa Species, BioResources, 5(3), 1384-1392, 2010. 
[13] J. Ruth Dodson, Wheat Straw Ash and Its Use as a Silica Source, Thesis, University of York Chemistry, 2011.

[14] J. Mastrodi Salgado, T. Aparecida Dias Bombarde, D. Niero Mansi, S. Maria de stefano Piedade, dan L. Maria Meletti, Effects of Different Concentrations of Passion Fruit Peel (Passiflora edulis) on the Glicemic Control in Diabetic Rat, Ciênc. Tecnol. Aliment., Campinas, Vol. 30(3), 784-789, ISSN 0101-2061, 2010.

[15] J. Sianipar, R. Krisnan, K. Simanihuruk, dan L. P. Batubara, Evaluasi Tiga jenis Limbah Pertanian sebagai Pakan Kambing Potong, Seminar Nasional Teknologi Peternakan dan Veteriner, Galang, hal 483, 2006.

[16] K.W Ragland, D.J Aerts, dan A.J Baker, Properties of Wood for Combustion Analysis, Bioresources Technology, hal 164, 1991.

[17] Khan, A.; Jong, W.; Jansens, P.; Spliethoff, $\mathrm{H}$ (2009) Biomass combustion in fluidized bed boilers: Potential problems and remidies. Fuel Process. Technol, hal 90, 21-50.

[18] M. K. Misra., K. W. Ragland dan A. J. Baker., Wood Ash Composition As a Function of Furnace Temperature. Biomass and Bioenergy, 4(2) 1993 : hal. 113, 1993.

[19] Najma., Pertumbuhan Nanokarbon Menggunakan Karbon Aktif dari Limbah Kulit Pisang dengan Metode Pirolisis Sederhana dan Dekomposisi Metana, Skripsi, Departemen Teknik Kimia, Fakultas Teknik, Universitas Indonesia, 2012.

[20] P. Quaak, H. Knoef, dan H. Stassen., Energy from Biomass, A Review of Combustion and Gasification Technologies, World Bank: Washington, DC, USA, 1999.

[21] Rio Latifan dan Diah Susanti, Aplikasi Karbon Aktif dari Tempurung Kluwak (Pangium Edule) dengan Variasi Temperatur Karbonisasi dan Aktivasi Fisika Sebagai Electric Double Layer Capasitor (EDLC), Jurnal Teknik Material dan Metalurgi, Vol 1. No. 1, 2, 2012.

[22] Robert. H. Perry dan Don W. Green., Perry's Chemical Engineers HandbookPhysical and Chemical Data, Edisi Ke-7, McGraw-Hill Company, Inc. 1999.

[23] S. Siahaan., M. Hutapea dan R. Hasibuan., Penentuan Kondisi Optimum Suhu dan Waktu Karbonisasi pada Pembuatan Arang dari Sekam Padi, Jurnal Teknik Kimia, Vol. 2, No 1, 2013.

[24] Supriyatna dan Erwin Sihite, Proses Pengolahan Limbah Kulit Buah Markisa sebagai Campuran Pakan Ternak Ruminansia, Teтu Teknis Nasional Tenaga Fungsional Pertanian, Galang, hal 197-199, 2006.

[25] Sutiyono dan Luluk Edahwati, Pemanfaatan Kulit Kemiri untuk Pembuatan Arang Aktif dengan Cara Pirolisis, Jurnal Penelitian Ilmu Teknik, Vol 6, No. 2, 135-136, 2006.

[26] W. Dian Jauharah., Analisis Kelistrikan yang Dihasilkan Limbah Buah dan Sayuran sebagai Energi Alternatif Bio-baterai, Skripsi, Jurusan Fisika, Fakultas Matematika dan Ilmu Pengetahuan Alam Universitas Jember, 2013. 